\title{
Identifikasi Cendawan Patogen pada Tanaman Sorgum di Timor Tengah Utara
}

\author{
Aloysius Rusae ${ }^{a}$, Bernadina Metboki ${ }^{b}$, dan Blasius Atini ${ }^{\mathrm{c}}$ \\ ${ }^{a}$ Fakultas Pertanian, Universitas Timor, Kefamenanu, TTU - NTT, Indonesia, email: alorusae@yahoo.com \\ ${ }^{b}$ Fakultas Pertanian, Universitas Timor, Kefamenanu,TTU - NTT, Indonesia, email: dinametboki28@gmail.com \\ ${ }^{c}$ Fakultas Ilmu Pendidikan, Universitas Timor, Kefamenanu, TTU - NTT, Indonesia, email: blasatini@yahoo.com
}

\section{Article Info}

\section{Article history:}

Received 2 Oktober 2018

Received in revised form 12 Oktober 2018

Accepted 17 Oktober 2018

DOI:

https://doi.org/10.32938/sc.v3i04.463

\section{Keywords:}

Busuk Batang

Hawar Daun

Karat Daun
Karakter Morfologi

\begin{abstract}
Abstrak
Sorgum adalah tanaman lokal di Timor Tengah Utara (TTU). Keberadaan penyakit tanaman sorgum belum diketahui di daerah ini. Penelitian ini bertujuan untuk mengidentifikasi cendawan patogen yang menyerang tanaman sorgum di Kabupaten Timor Tengah Utara, Provinsi Nusa Tenggara Timur. Penelitian dilakukan secara eksperimental dengan Rancangan Acak Kelompok (RAK). Perlakuan terdiri atas 4 varietas sorgum yakni (V1) varietas Lokal Merah, (V2) Lokal Putih, (V3) Lokal Hitam, dan (V4) Numbu. dari perlakuan diulang 3 kali sehingga terdapat 12 petak percobaan. Pengamatan penyakit dan identifikasi patogen menggunakan karakter morfologi. Hasil penelitian menunjukkan penyakit-penyakit yang menyerang tanaman sorgum adalah hawar daun, busuk batang dan karat daun. Penyakit hawar daun, karat daun dan penyakit busuk batang merupakan penyakit terpenting pada tanaman sorgum di TTU. Intensitas kejadian penyakit berkisar 4,25\%- 51,17\% dan keparahan penyakit berkisar 60,68-83,73\%. Penyakit busuk batang yang disebabkan oleh Rhizoctonia sp. dapat menginfeksi semua varietas Sorgum namun tidak menimbulkan keparahan penyakit. Penyakit Karat menginfeksi varietas Lokal Putih dan Lokal Merah, dengan nilai keparahan penyakit tertinggi terdapat pada varietas Lokal Putih yaitu penyakit $(83,73 \%)$. Sebaliknya penyakit Hawar Daun yang disebabkan Helmithosporium sp, hanya terdapat pada varietas Lokal Hitam dan Numbu dengan nilai keparahan penyakit tertinggi terdapat pada varietas Numbu yaitu $49,60 \%$.
\end{abstract}

\section{Pendahuluan}

Sorgum merupakan tanaman pangan penting dan sebagai pangan dunia sorgum berada diperingkat ke-5 setelah gandum, padi, jagung, dan barley. Biji sorgum mengandung tiga jenis karbohidrat yaitu, pati, gula terlarut, dan serat. Kandungan protein sorgum seimbang dengan jagung, kandungan protein sorgum adalah sebesar $10,11 \%$ sedangkan jagung $11,02 \%$. Kandungan pati, sorgum $80,42 \%$ sedangkan jagung $79,95 \%$ (BPTP, 2013). Penggunaan sorgum sangat beragam, tetapi secara garis besar dapat digolongkan menjadi tiga kelompok yaitu sebagai bahan pangan, bahan pakan, dan bahan industri (Sumarno \& Karsono, 1996).

Sorgum dapat tumbuh pada hampir semua jenis tanah, dan mempunyai kemampuan adaptasi yang luas. Komoditi ini mempunyai daya adaptasi tinggi yaitu lebih tahan terhadap kekeringan bila dibandingkan dengan tanaman serealia lainnya. Oleh karena itu, sorgum merupakan tanaman yang sangat berpotensi untuk dikembangkan menjadi salah satu tanaman alternatif dalam memenuhi kebutuhan pangan, pakan, dan industri. (Sirappa, 2003).

Pertumbuhan tanaman sorgum di daerah ini tidak luput dari serangan penyakit. Serangan penyakit oleh beberapa patogen menginfeksi batang, daun dan buah. Penyakit- penyakit tersebut tidak dapat dikendalikan dan mengganggu pertumbuhan dan produksi sorgum. Hai ini sesuai dengan penelitian Soenartiningsih $d k k .$, (2015) Penyakit yang merusak pertanaman sorgum adalah penyakit antraknose yang disebabkan oleh Colletroticum sp, bercak daun yang disebabkan oleh Helminthosporium sp, penyakit busuk batang yang disebabkan oleh Fusarium, dan penyakit karat yang disebabkan oleh Puccinia.

Pengembangan sorgum di Kabupaten Timor Tengah Utara (TTU) Provinsi Nusa Tenggara Timur (NTT) secara tradisional dan belum memanfaatkan teknologi dalam mengoptimalkan pertumbuhan dan produksi tanaman tersebut. Tanaman ini sering terserang beberapa penyakit, namun belum diidentifikasi. Identifikasi penyakit secara umum adalah membuat kepastian terhadap suatu penyakit berdasarkan gejala yang tampak, atau suatu proses untuk mengenali suatu penyakit tanaman melalui gejala dan tanda penyakit yang khas termasuk faktor-faktor lain yang berhubungan dengan proses penyakit tersebut (Nurhayati, 2011).

Informasi tentang penyakit tanaman sorgum belum ada di daerah tersebut. Keberadaan patogen pada pertanaman sorgum belum diamati dan diidentifikasi. Pengetahuan tentang keberadaan patogen sangat penting untuk menentukan peta sebaran patogen, juga untuk menentukan langkah pengelolaan patogen tersebut lebih lanjut sehingga diharapkan dapat meningkatkan produksi sorgum. Oleh karena itu penelitian ini dilakukan untuk mengidentifikasi cendawan patogen yang menyerang tanaman sorgum di Kabupaten TTU, Provinsi NTT.

\section{Metode Penelitian}

Budidaya sorgum dilaksanakan di Naen, Kelurahan Tubuhue, dan pengamatan sampel dilakukan di Laboratorium Fakultas Pertanian, Universitas Timor mulai bulan April sampai bulan November 2017

Tata letak budidaya sorgum dilaksanakan menggunakan Rancangan Acak Kelompok (RAK) dengan 3 kali ulangan (Gomez \& Gomez, 1984). Perlakuan terdiri atas 4 varietas sorghum yakni (V1) varietas Lokal Merah, (V2) Lokal Putih, (V3) Lokal Hitam, dan (V4) Numbu. dari perlakuan diulang 3 kali sehingga terdapat 12 petak percobaan.

Penanaman diawali dengan persiapan lahan. Tanah dicangkul sedalam 25 $30 \mathrm{~cm}$ kemudian tanah cangkulan digembur dan membuat petak dengan ukuran $660 \mathrm{~cm}$ x $210 \mathrm{~cm}$. Lahan penelitian dibagi menjadi 3 blok dan setiap blok terdiri dari 4 petak, jumlah keseluruhan petak dalam penelitian ini adalah 12 petak. Setelah pengolahan tanah, dilanjutkan dengan pemberian pupuk dasar menggunakan jenis pupuk kandang sapi dengan dosis 5 ton/ ha. Penanaman dilakukan secara tugal, 2 benih per lubang tanam pada kedalaman $\pm 5 \mathrm{~cm}$. Jarak tanam yang digunakan yaitu $60 \mathrm{~cm} \times 20 \mathrm{~cm}$. Benih sorghum yang digunakan adalah varietas Numbu, Lokal Putih, Lokal Merah dan lokal Belu (Malai).
Pengamatan terhadap kejadian penyakit dilakukan pada setiap petak perlakuan dan seluruh tanaman yang terdapat pada petak tersebut menjadi tanaman sampel. Pengamatan kejadian penyakit yakni menghitung jumlah tanaman sampel yang terserang patogen. Menghitung persentase kejadian penyakit (KP) menggunakan rumusan (Zadoks \& Schein, 1979):

$$
\mathrm{Kp}=\frac{\mathrm{n}}{\mathrm{N}} \times 100 \%
$$

dimana:

$$
\begin{array}{ll}
\mathrm{Kp} & =\text { kejadian penyakit; } \\
\mathrm{n} & =\text { jumlah tanaman yang terserang patogen; dan } \\
\mathrm{N} & =\text { jumlah tanaman yang diamati dalam setiap perlakuan. }
\end{array}
$$

Pengamatan keparahan penyakit dilakukan pada setiap petak perlakuan pada petak-petak tersebut dilakukan pengacakan untuk menentukan 10 rumpun sorgum sebagai tanaman sampel yang ditandai dengan pengajiran pada tanaman atau rumpun tersebut, pada awal pertumbuhan sorgum. Pengamatan terhadap keparahan penyakit dilakukan dengan cara mengamati tanaman sampel yang terserang penyakit dan diberikan skor sesuai dengan skoring penyakit yang sudah ditentukan. Untuk menghitung keparahan penyakit digunakan rumus (Horsfall \& Barratt, 1945):

$$
\mathrm{IP}=\frac{\Sigma \text { ni.vi }}{\mathrm{N} . \mathrm{V}} \times 100 \%
$$

dimana:

$$
\begin{aligned}
\text { IP } & =\text { keparahan penyakit; } \\
\text { ni } & =\text { jumlah tanaman dengan skor ke-1; } \\
\text { vi } & =\text { nilai skor penyakit; } \\
\mathrm{N} & =\text { jumlah tanaman yang diamati; dan } \\
\mathrm{V} & =\text { skor tertinggi. }
\end{aligned}
$$

Isolasi patogen penyebab penyakit dilakukan dengan pengambilan sampe daun, batang dan akar dari lahan penelitian. Bagian tanaman yang terserang penyakit dicuci bersih, dengan air kemudian dipotong-potong dengan ukuran \pm $3 \mathrm{~cm}$. Potongan-potongan tersebut dicelupkan dalam bahan aktif natrium hipoklorit $1 \%$ dan alkohol $70 \%$ masing-masing selama 1 menit, kemudian dibilas dengan air steril sebanyak tiga kali dan selanjutnya dikeringkan di atas kertas saring. Potongan daun, batang dan akar tersebut ditanam di dalam cawan petri yang telah diisi dengan media PDA. Penutupan cawan petri dilakukan dengan sangat rapat untuk mencegah inokulan terkontaminasi. Inkubasi dilakukan pada suhu kamar. Cendawan yang tumbuh dalam cawan petri kemudian dimurnikan untuk mendapatkan biakan murni. Semua pekerjaan dilakukan secara aseptik.

Karakterisasi cendawan patogen dilakukan pengamatan secara makroskopis dan mikroskopis. Secara makroskopis yaitu pengamatan secara langsung melihat ciri khas koloni seperti warna, bentuk dan tepi koloni. Secara mikroskopis yaitu pengamatan terhadap karakteristik cendawan berupa 1) hifa: warna, bersekat atau tidak, pola dan ukuran percabangan; (2) konidia: bentuk, warna dan ukuran; dan 3) konidiofor: warna, bersekat atau tidak, bercabang atau tidak. Cendawan patogen yang diperoleh diidentifikasi dengan kunci identifikasi (Putterill, (1954); Robert, (1999): Manamgoda $d k k$., (2014); dan Toda $d k k$. (2007)).

\section{Hasil dan Pembahasan}

\subsection{Penyakit Sorgum di Timor Tengah Utara.}

Penyakit yang menginfeksi tanaman sorgum di TTU ialah penyakit busuk batang, hawar daun dan karat. 


\section{a. Penyakit Busuk Batang}

Gejala khas penyakit busuk batang adalah pertumbuhan tanaman kerdil, tidak subur dan tidak berproduksi, bila berproduksi sedikit bernas. Pada daun terdapat bercak kuning berkembang menjadi bercak coklat kemudian nekrotik dan kering. Pangkal batangnya berwarna coklat kehitaman dan puntung akarnya (Gambar 1.). Hal ini sesuai dengan hasil penelitian (Soenartiningsih $d k k$., 2015) gejala sorgum awalnya terdapat di pelepah atau helai daun berupa bercak/hawar berwarna agak kemerahan, dan berubah menjadi abu-abu.

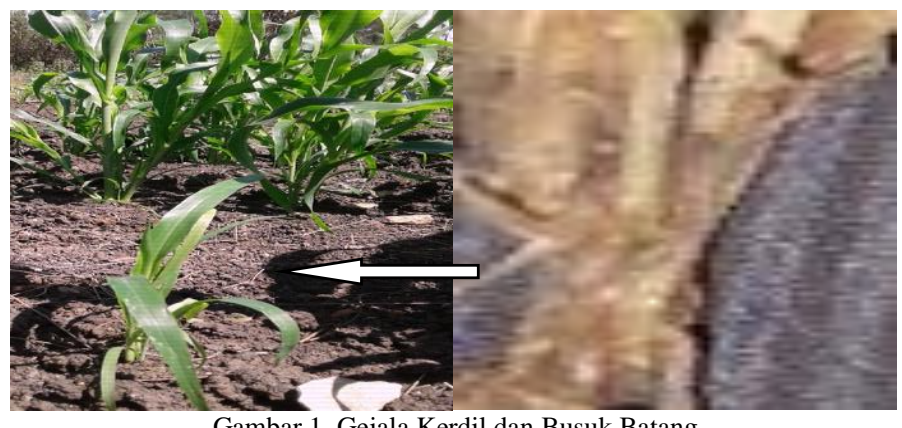

Gambar 1. Gejala Kerdil dan Busuk Batang

\section{b. Penyakit Karat}

Tanaman sorgum bergejala karat pada $16 \mathrm{hst}$. Serangan berawal dari daun pertama dan menyebar ke daun lain seiring bertambahnya waktu. Pada daun terdapat titik-titik noda berwarna merah kecokelatan seperti karat dan selanjutnya menginfeksi memenuhi permukaan daun (Gambar 2.). Daun yang terserang lebih awal mengalami nekrotik dan gugur. Gejala penyakit karat terdapat titik-titik noda berwarna merah kecokelatan seperti karat serta terdapat serbuk berwarna kuning kecokelatan (Novemprirenta $d k k$. 2013). Selanjutnya terjadi peningkatan intensitas penyakit setiap minggunya keadaan ini didukung dengan intensitas hujan yang semakin meningkat pada saat penelitian. Menurut Vincelli \& Hershman, (1997) Kelembaban udara yang tinggi akan meningkatkan serangan penyakit karat. Cendawan penyebab karat menginfeksi daun ketika spora dihasilkan dan permukaan daun dalam keadaan basah, sering lebih parah pada penanaman akhir.

Pucinia menyebabkan penyakit karat pada tanaman sorgum. Intensitas hujan yang tinggi dan suhu renda pada lokasi penelitian menyebabkan Pucinia sp beraktivitas dan menginfeksi tanaman sorgum. Respon tanaman terhadap infeksi penyakit berkisar 4,25-21,6\% pada varietas Lokal Merah dan Lokal Putih. Tingkat keparahan mencapai $83,3 \%$. intensitas penyakit karat cenderung semakin meningkat dengan pertambahan umur tanaman menuju dewasa

Tanaman sorgum yang toleran terhadap karat adalah Lokal Hitam dan Numbu, kedua varietas tersebut tidak ditemukan gejala karat. Menurut Agrios, (2004), ini menunjukkan bahwa mekanisme pertahanan kimia (preexistingchemical) lebih bertanggungjawab dari pada yang bersifat struktural (preexisting structural) untuk resistensi tanaman terhadap infeksi yang ditunjukkan oleh tanaman terhadap patogen tertentu.

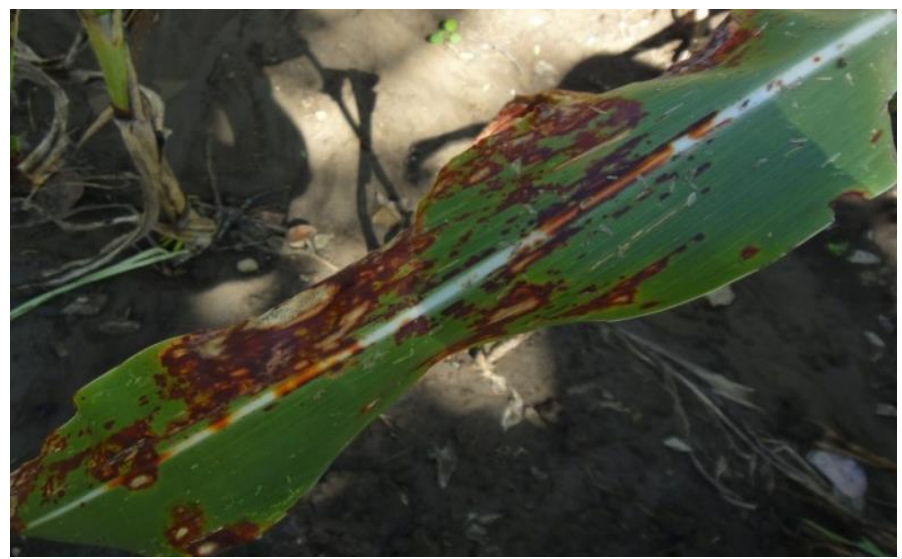

Gambar 2. Gejala Karat di Lapangan

\section{c. Penyakit Hawar Daun}

Gejala penyakit hawar daun mulai tampak pada fase vegetatif yakni 12 hst. Gejala awal pada daun pertama, berupa bercak kecil pada permukaan daun yang dikelilingi warna kekuningan, selanjutnya bercak-bercak membesar membentuk lesi yang memanjang di antara tulang daun berwarna coklat. Bentuk bercak daun bervariasi dan cenderung tidak beraturan. Ukuran bercak semakin membesar dari waktu ke waktu dan semakin meluas hingga menutupi seluruh bagian daun, kemudian daun menjadi coklat, kering dan rapuh (Gambar 3.). Ha ini sesuai dengan penelitian Durga, (2002) gejala pertama kali muncul berupa bintik kuning kecokelatan kecil kemudian membesar berbentuk elips atau melingkar berukuran $3-5 \mathrm{~mm}$ kemudian daun yang terinfeksi mengalami nekrosis, infeksi pertama pada umumnya terjadi pada daun bagian bawah kemudian menjalar ke atas, bercak daun selain menyerang pada daun juga dapat menyerang pada bagian batang dan tangkai bulir apabila terjadi serangan yang tinggi.

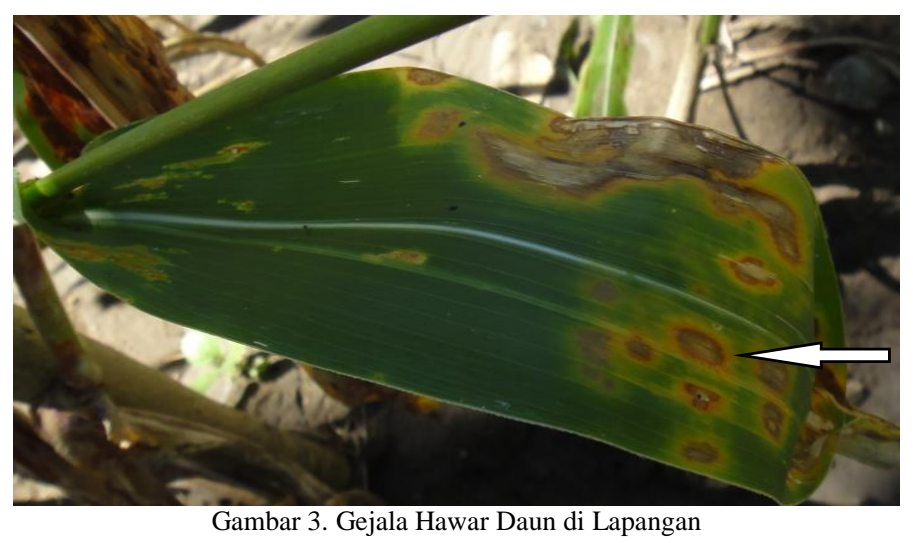

3.2 Kejadian dan keparahan Penyakit Hawar Daun, Karat dan Kerdil. Terdapat perbedaan kejadian dan keparahan penyakit pada 4 varietas. Kejadian penyakit busuk batang pada varietas Numbu lebih tinggi dengan varietas lain dan berbeda nyata dengan varietas Lokal Putih dan Merah. Penyakit karat menginfeksi varietas Lokal Merah dengan persentase kejadian penyakit tertinggi dan berbeda nyata dengan Lokal Putih, pada varietas Lokal Hitam dan Numbu tidak terserang patogen tersebut. Varietas Numbu memiliki tingkat kejadian penyakit hawar daun tertinggi dan berbeda nyata dengan varietas Lokal Hitam dan patogen ini tidak menginfeksi varietas Lokal Merah dan Putih Keparahan penyakit karat dan bercak semakin berkembang seiring pertumbuhan tanaman. Keparahan penyakit hawar daun yang tertinggi terdapat pada varietas Lokal Putih dan berbeda nyata dengan Lokal Merah. Varietas Numbu terserang penyakit bercak dengan intensitas keparahan tertinggi dan berbeda nyata dengan lokal hitam (Tabel 1.)

Tabel 1. Data Kejadian Penyakit dan Keparahan Penyakit pada Beberapa Varietas Sorgum yang Ditanam pada Lahan Kering.

\begin{tabular}{llllllll}
\hline \multirow{2}{*}{ Penyakit } & \multirow{2}{*}{ Varietas } & \multicolumn{3}{c}{ Kejadian Penyakit } & \multicolumn{2}{c}{ Keparahan Penyakit } \\
\cline { 3 - 8 } & & $4 \mathrm{mst}$ & $8 \mathrm{mst}$ & $12 \mathrm{mst}$ & $4 \mathrm{mst}$ & $8 \mathrm{mst}$ & $12 \mathrm{mst}$ \\
\hline \multirow{3}{*}{ Busuk } & Lokal Merah & $3,21 \mathrm{a}$ & $12 \mathrm{a}$ & $20,93 \mathrm{a}$ & - & - & - \\
Batang & Lokal Putih & $2,78 \mathrm{a}$ & $10,32 \mathrm{a}$ & $20,89 \mathrm{a}$ & - & -- & - \\
& Lokal Hitam & $2,80 \mathrm{a}$ & $13,65 \mathrm{a}$ & $42,48 \mathrm{~b}$ & - & - & - \\
& Numbu & $3,50 \mathrm{a}$ & $26,74 \mathrm{~b}$ & $51,17 \mathrm{~b}$ & - & - & -- \\
\hline \multirow{4}{*}{ Karat } & Lokal Merah & $2,83 \mathrm{a}$ & $5,32 \mathrm{a}$ & $21,63 \mathrm{~b}$ & $19,22 \mathrm{a}$ & $52,33 \mathrm{a}$ & $72 \mathrm{a}$ \\
& Lokal Putih & $1,64 \mathrm{a}$ & $2,38 \mathrm{a}$ & $4,25 \mathrm{a}$ & $20,21 \mathrm{a}$ & $56,46 \mathrm{a}$ & $83,73 \mathrm{~b}$ \\
& Lokal Hitam & $0 \mathrm{a}$ & $0 \mathrm{a}$ & $0 \mathrm{a}$ & - & - & - \\
& Numbu & $0 \mathrm{a}$ & $0 \mathrm{a}$ & $0 \mathrm{a}$ & - & - & - \\
\multirow{3}{*}{ Hawaryyyyyyy daun } & Lokal Merah & $0 \mathrm{a}$ & $0 \mathrm{a}$ & $0 \mathrm{a}$ & - & - & - \\
& Lokal Putih & $0 \mathrm{a}$ & $0 \mathrm{a}$ & $0 \mathrm{a}$ & - & - & - \\
& Lokal Hitam & $4,14 \mathrm{a}$ & $9,12 \mathrm{a}$ & $20,99 \mathrm{~b}$ & $20,84 \mathrm{a}$ & $61,60 \mathrm{a}$ & $60,68 \mathrm{a}$ \\
& Numbu & $6,17 \mathrm{a}$ & $24,89 \mathrm{~b}$ & $49,60 \mathrm{c}$ & $21,12 \mathrm{a}$ & $63,72 \mathrm{a}$ & $74,72 \mathrm{~b}$
\end{tabular}

\subsection{Identifikasi Morfologi dan Mikroskopis}

a. Penyakit Busuk Batang

Hasil pengamatan morfologi terhadap cendawan patogen penyebab penyakit busuk batang yaitu koloni berwarna putih, dengan tepian rata. Miselia cendawan bercabang membentuk jala halus dan bersekat. Hifa mempunyai percabangan yang tegak lurus. Pada hari ke 30 terbentuk sklerotia berwarna putih berubah menjadi coklat hingga kehitaman dengan bentuk tidak beraturan (Gambar 4.) Menurut Soenartiningsih, (2009) hifa R. Solani yang masih muda mempunyai percabangan yang membentuk sudut $45^{\circ} \mathrm{C}$, semakin dewasa percabangannya tegak lurus, kaku, dan mempunyai ukuran yang sama. Sklerotium dari $R$. Solani terbentuk dari hifa yang mengalami agregasi menjadi massa yang kompak. Sklerotium pada awal pertumbuhan berwarna putih dan setelah dewasa berubah menjadi cokelat. Bentuk sklerotium pada umumnya bulat atau tidak beraturan, dan ukurannya bervariasi, bergantung pada isolatnya.

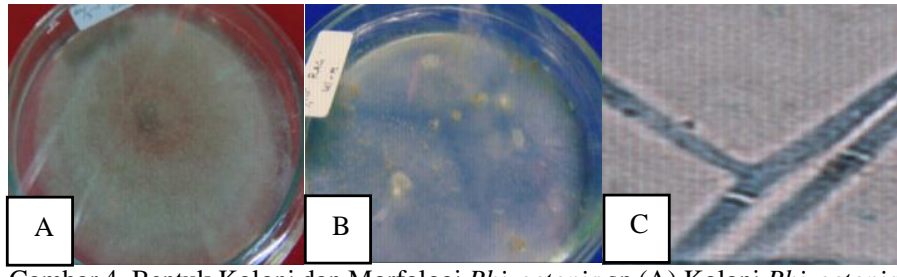

Gambar 4. Bentuk Koloni dan Morfologi Rhizoctonia sp (A) Koloni Rhizoctoni sp pada Media PDA. (B) Sklerotia. (C) Hifa Rhizoctonia sp

Lahan penelitian selalu ditanami jagung, sorgum, kacang kacangan yang menjadi sumber iniokulum pada musim tanam berikutnya dan pada saat penelitian intensitas hujan tinggi menyebabkan intensitas penyakit semakin tinggi. Cendawan $R$. Solani mempunyai tanaman inang yang sangat luas, selain 
pada tanaman dari familia gramineae termasuk serealia yaitu jagung, sorgum, gandum, rumput dan padi. Cendawan R. Solani dapat berkembang baik pada kelembaban yang tinggi $(>80 \%)$ dan suhu $15-35^{\circ} \mathrm{C}$. Cendawan $R$. Solani adalah patogen tular tanah yang banyak merusak tanaman, mempunyai kemampuan adaptasi yang tinggi, dan dapat bertahan hidup dalam tanah dengan waktu yang lama dalam bentuk sklerotia (Semangun, 2008).

Penyakit busuk batang disebabkan oleh cendawan Rhizoctonia dan intensitas serangan sangat tinggi dibandingkan dengan penyakit lainnya. Kejadian penyakit busuk batang pada tanaman sorgum berkisar 20,93-51,17\% Keberadaan Patogen ini diduga berasal dari benih dan pada lokasi penelitian ditanami jagung, terung yang menjadi inang alternatif berperan sebagai sumber inokulum. Cendawan $R$. Solani mempunyai tanaman inang yang sangat luas, selain pada tanaman dari familia gramineae termasuk serealia yaitu jagung, sorgum, gandum, rumput dan padi. Cendawan ini juga menyerang tanaman dari familia Leguminoceae (Kacang-kacangan), Solanaceae dan juga famili Cucurbitaceae (Semangun, 2008).

Intensitas infeksi patogen busuk batang terhadap respon varietas berbeda. Varietas Lokal Putih paling tahan dan varietas Numbu sangat rentan. Tingginya serangan pada varietas Numbu dapat disebabkan karena varietas tersebu memiliki daya tahan yang rendah dan merupakan tanaman introduksi yang belum beradaptasi dengan lingkungan.

b. Penyakit Hawar Daun

Berdasarkan hasil pengamatan mikroskopik hasil isolasi pada medium PDA menunjukkan bahwa koloni cendawan berwarna putih kehijauan sampa kehitaman. konidium Cendawan awalnya berwarna hialin, kemudian berwarna kuning kecokelatan sampai kehitaman, memiliki banyak sekat. Konidium berbentuk oval panjang terkadang konidium lurus atau agak melengkung, bagian tengahnya membesar dan kedua ujungnya mengecil dan tumpul, berdinding tebal, Hifa cendawan ini bersekat, hialin dan matang menjadi kuning kecokelatan (Gambar 5.). Berdasarkan karakter morfologi dan pertumbuhan koloni, isolat dari sorgum adalah genus Helminthosporium (Putterill, 1954).

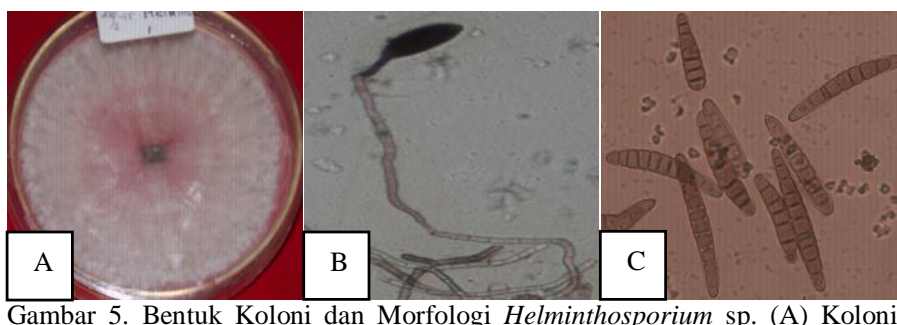
Helminthosporium pada Media PDA. (B) Konidiafor. (C) Konidia

Penyakit bercak daun disebabkan oleh Helminthosporium. Intensitas kejadian penyakit yang terdapat pada varietas Numbu sebesar 49,60\% pada varietas Lokal Putih sebesar 20,99\%. Varietas Lokal Hitam dan Lokal Merah tahan terhadap infeksi patogen. Kedua varietas toleran terhadap Helminthosporium. Patogen ini berkembang di daerah ini karena Pelaku budidaya selalu menanam jagung, rerumputan serta tumbuh gulma di area penelitian dan pada saat penelitian intensitas hujan yang tinggi dan menjadi lingkungan yang sesuai pertumbuhannya. Perkembangan penyakit ditentukan oleh kondisi lingkungan dan penyebarannya hampir di seluruh dunia dan inangnya juga dari beberapa tanaman serealia. Perkembangan penyakit in toleransi suhunya cukup besar untuk perkembangan konidia yaitu antara 18 - 32 ${ }^{0} \mathrm{C}$ dan kelembaban yang dibutuhkan sekitar $80-90 \%$ (Putterill, 1954).

\section{Simpulan}

Penyakit utama yang menginfeksi tanaman sorgum di TTU adalah busuk batang, penyakit karat dan hawar daun. Penyakit busuk batang yang disebabkan oleh Rhizoctonia sp. dapat menginfeksi semua varietas Sorgum. Angka Kejadian Penyakit paling tinggi terdapat pada varietas Numbu yaitu $51,17 \%$. Penyakit Karat hanya menginfeksi dua varietas yang ditanam, yaitu Lokal Merah dan Lokal Putih. Penyakit ini menimbulkan nilai keparahan penyakit yang lebih tinggi dan berbeda nyata pada varietas Lokal Putih $(83,73 \%)$ dibandingkan Lokal Merah (72\%). Sebaliknya pada penyakit Hawar Daun yang disebabkan Helmithosporium sp, hanya terdapat pada varietas Lokal Hitam dan Numbu dengan nilai keparahan penyakit tertinggi terdapat pada varietas Numbu yaitu $49,60 \%$.

\section{Pustaka}

Agrios, G. W. 2004. Plant Pathology. New York.: Academic Press

Balai Pelatihan dan Teknologi Pertanian, 2013. Sorgum Komunitas Serealia Bergizi yang Toleran Kekeringan. Maros (ID): Balit Serealia Maros, Sulawesi Selatan.

Durga, K.K, 2002. Leaf blight exserohilum turcicum (Pass) of sorghum. Agric. Rev.,23 (3) : 175 - 184

Gomez, K.A. \& Gomez, A.A. 1984. Statistical Procedures for Agricultural Research. New York: John Wiley \& Sons.

Horsfall JG, Barratt RW. 1945. An improved grading system for measuring plant disease. Phytopathology. 35:655.

Manamgoda DS, Rossman AY, Castlebury LA, Crous PW, Madrid H, ChukeatiroteE. 2014. The genus Bipolaris. Stud Mycol. 79:221-288.
Novemprirenta YC, Indriyani S, Prayogo Y 2013. Respon Beberapa Galur Sorgum [Sorghum bicolor (L.) Moench] terhadap Penyakit Karat Daun (Puccinia sorghi Schw.) Jurnal Biotropika. 1(2) 33-35

Nurhayati 2011. Epidemiologi Penyakit Tumbuhan. Ed ke-1. Palembang (ID): Universitas Sriwijaya.

Putterill KM. 1954. Some graminicolous species of Helminthosporium and Curvularia occurring in South Africa. Bothalia 6(2): 347-378

Roberts P. 1999. Rhizoctoniaforming fungi. 1th ed. Netherlands (NL):CBS KNAW.

Semangun, H. 2008. Penyakit-penyakit tanaman tangan di Indonesia. (Edisi kedua). Gadjah Mada University Press, Yogyakarta.

Sirappa, M. P. 2003. Prospek Pengembangan Sorgum di Indonesia Sebagai Komoditas Alternatif untuk Pangan, Pakan dan Industri. Jurnal Litbang Pertanian.22:133-140.

Soenartiningsih. 2009. Histologi dan kerusakan oleh jamur $R$. Solanipenyebab penyakit busuk pelepah pada jagung. Prosiding Seminar Nasional Biolog XX dan Kongres Perhimpunan Biologi Indonesia XIV. Malang 24-25 Juli 2009.

Soenartiningsih, Akil M., dan Andayani NN. 2015. Cendawan Tular Tanah (Rhizoctoniasolani) Penyebab Penyakit Busuk Pelepah pada Tanaman Jagung dan Sorgum dengan Komponen Pengendaliannya. Iptek Tanaman Pangan. 10(2):85-87

Sumarno dan S. Karsono. 1996. Perkembangan produksi sorgum di dunia dan penggunaan-nya. Risalah Simposium Prospek Tanaman Sorgum untuk Pengembangan Agroindusqtri, 17-18 Januari 1995.

Toda T, Hayakawa T, Mghalu JM, Yaguchi S, Hyakumachi M. 2007. A new Rhizoctonia sp. closely related to Waitea circinata causes a new disease of creeping bentgrass. J Gen Plant Pathol. 73: 379-387.

Vincelli, P. \& D. E. Hershman. 1997. Kentucky plant disease management guide for corn and sorghum. Extension plant pathologists. University of Kentucky.

Zadok JC, ScheinRD. 1979. Epidemology and Plant Disease Management. New York (USA): Oxford University Press. 